\title{
Effect of microencapsulation and mango peel powder on probiotics survival in ice
}

\section{cream}

\section{Efeito da microencapsulação e pó de casca de manga na sobrevivência de probióticos em sorvete}

\author{
María Hayayumi-Valdivia1* (1), Luis Francisco Márquez-Villacorta1, \\ Carla Consuelo Pretell-Vásquez ${ }^{1}$
}

${ }^{1}$ Universidad Privada Antenor Orrego, Facultad de Ciencias Agrarias, Escuela de Ingeniería en Industrias Alimentarias, Trujillo, La Libertad - Peru

*Corresponding Author: María Hayayumi-Valdivia, Universidad Privada Antenor Orrego, Facultad de Ciencias Agrarias, Escuela de Ingeniería en Industrias Alimentarias, Avenida América Sur, 3145, Urbanización Monserrate, La Libertad, 51, Trujillo - Peru, e-mail: mhayayumiv@upao.edu.pe

Cite as: Hayayumi-Valdivia, M., Márquez-Villacorta, L. F., \& Pretell-Vásquez, C. C. (2021). Effect of microencapsulation and mango peel powder on probiotics survival in ice cream. Brazilian Journal of Food Technology, 24, e2019309. https://doi.org/10.1590/1981-6723.30919

\begin{abstract}
This study evaluated the effect of microencapsulation and addition of mango peel powder on the survival of Lactobacillus acidophilus and Bifidobacterium lactis, overrun, apparent viscosity, and overall acceptability of symbiotic ice cream during storage at $-20{ }^{\circ} \mathrm{C}$ for 180 days. Six formulations of vanilla-flavored ice cream were prepared: three with addition of probiotic cultures at a concentration of $10^{8} \mathrm{CFU} / \mathrm{g}$ and $0,2 \%$, and $3 \%$ mango peel powder microencapsulated in a sodium alginate matrix, and three with free addition. Analytical evaluations were performed after 1, 30, 60, 90, 120 and 180 days of storage. The results showed that microencapsulation of probiotics and prebiotics statistically influenced $(p<0.05)$ the characteristics evaluated. The formulation with microencapsulated probiotics and $2 \%$ mango peel powder was considered as the best product. This formulation is promising for future commercial application as a functional food because, at the end 180 days of storage, it showed probiotics population $>10^{6} \mathrm{CFU} / \mathrm{g}, 72.97 \%$ overrun, $292 \mathrm{mPA}$ apparent viscosity, and good overall acceptance (7.6 points) equivalent to "I like it very much".
\end{abstract}

Keywords: Co-encapsulation; Symbiotic; Probiotics; Lactobacillus acidophilus; Bifidobacterium lactis; Ice cream; Mango peel; By-products.

\section{Resumo}

O efeito da microencapsulação e da adição de casca de manga em pó na sobrevivência de Lactobacillus acidophilus e Bifidobacterium lactis, overrun, viscosidade aparente e aceitabilidade geral de sorvete simbiótico durante o armazenamento a $-20^{\circ} \mathrm{C}$ por 180 dias foram avaliados. Foram elaboradas seis formulações de sorvete com sabor de baunilha, dentre as quais três foram adicionadas com culturas probióticas em uma concentração de $10^{8} \mathrm{CFU} / \mathrm{g}$ e casca de manga em pó em $0,2 \%$ e $3 \%$ microencapsuladas em uma matriz de alginato de sódio e as outras três foram adicionadas livremente. Foram realizadas avaliações analíticas em 1, 30, 60, 90, 120 e 180 dias de 
armazenamento. Os resultados mostraram que a microencapsulação de probióticos e prebióticos influenciaram estatisticamente $(p<0,05)$ os parâmetros avaliados. A formulação com probióticos microencapsulados e $2 \%$ de casca de manga em pó foi considerada como o melhor produto com uma futura aplicação comercial como alimento funcional, pois, aos 180 dias de armazenamento mantinha a população probiótica acima de 106 UFC/g, 72,97\% de overrun, 292 mPA de viscosidade aparente e obteve uma boa aceitação geral (média de 7,6 pontos).

Palavras-chave: Co-encapsulamento; Simbiótico; Probióticos; L. acidophilus; B. lactis; Sorvete; Casca de manga; Subprodutos.

\section{Introduction}

Probiotics are defined as "live microorganisms that, when administered in adequate amounts, confer a health benefit on the host" (Hill et al., 2014). For sustaining positive effects in humans, the probiotic carrier must contain a high quantity of probioactives and maintain sufficient viable numbers $\left(10^{6}\right.$ to $10^{7} \mathrm{CFU} / \mathrm{g}$ of carrier food product) at the time of consumption (Guarner et al., 2017; Champagne et al., 2018; Ranadheera et al., 2018).

Prebiotics are substrates that beneficially affect host organisms by selectively stimulating the growth and/or activity of populations of bacteria in the gut. Currently established prebiotics are carbohydrate-based, but other substances such as polyphenols and polyunsaturated fatty acids converted to respective conjugated fatty acids might fit the updated definition, assuming a convincing weight of evidence in the target host (Gibson et al., 2017). The processing of fruits, such as mango, generates a large number of agro-industrial by-products, which are mostly disposed in landfills and used in animal feed, but that could be used as prebiotics (Serrano-Casas et al., 2017) due to their dietary fiber content and antioxidant components (Serna Cock \& Torres León, 2015; Pacheco, 2015).

The dairy industry has found in probiotics a tool for the development of new functional products, with Lactobacillus and Bifidobacterium the most used strains (Cruz et al., 2009). Several studies have demonstrated the potential of ice cream as a vehicle for the inclusion of these beneficial microorganisms in the human diet (Balthazar et al., 2017; Kalicka et al., 2019; Araújo et al., 2012; Abghari et al., 2011), reporting a product with good acceptance and counts of probiotics $>10^{6} \mathrm{CFU} / \mathrm{g}$ at the end of shelf life. Dietary fiber from fruit processing residues has been investigated as a texturizing, stabilizing and emulsifying agent that generates a desirable effect on the physical, chemical and sensory properties of ice cream (Akalın et al., 2018; Ayar et al., 2018).

Microencapsulation has been used to protect probiotic bacteria from the reaction with other compounds and maintain their viability during processing, storage, and along the gastrointestinal tract (Martín et al., 2015; Caicedo, 2010). Other compounds can be added to improve the stability of the capsules and the viability of microencapsulated microorganisms (Pradeep Prasanna \& Charalampopoulos, 2019; Peredo, 2014).

The present study evaluated the effect of microencapsulation and addition of mango peel powder on the survival of probiotics as an alternative to obtain sensory acceptable ice cream with beneficial characteristics for health.

\section{Materials and methods}

\subsection{Preparation of mango peel powder}

The method described by Jibaja Espinoza (2014) was followed. Peels of ripe mangoes were collected from juice processing stalls in the municipality of Trujillo, Peru. They were washed and disinfected with a $100 \mathrm{ppm}$ chlorine dioxide solution. Moisture excess was removed from the peels and they were then cut into rectangles 
approximately $2 \mathrm{~cm}$ wide and $3 \mathrm{~cm}$ long. After that, they were placed in a forced-air dehydrator at $55^{\circ} \mathrm{C}$ for $6 \mathrm{~h}$ until moisture content $\leq 10 \%$ was reached. Finally, using a hammer mill (F-180, China), they were reduced in size and then sifted through a Tyler no. 120 mesh (125 um).

\subsection{Activation of probiotic cultures}

Lyophilized cultures of Lactobacillus acidophilus (Centro Sperimentale del Latte, Italy) and Bifidobacterium lactis (Centro Sperimentale del Latte, Italy) were inoculated separately in glass tubes containing De Man Rogosa Sharpe (MRS) broth in $1: 10$ ratio and incubated at $37^{\circ} \mathrm{C}$ for $24 \mathrm{~h}$ under aerobic conditions. Then they were centrifuged at $4000 \mathrm{rpm}$ at $4{ }^{\circ} \mathrm{C}$ for $10 \mathrm{~min}$, washed twice with $0.9 \%$ sterile saline under the same centrifugation conditions; the resulting pellet was diluted in $2 \mathrm{~mL}$ of $0.9 \%$ sterile saline (10 $0^{-1}$ dilution) (Khosravi Zanjani et al., 2014). The counts of L. acidophilus and B. lactis in the suspensions were enumerated by plate count on MRS agar. For L. acidophilus count, the spread plate method in MRS was used, whereas for $B$. Lactis count, the poured plate method with MRS agar supplemented with $0.5 \%$ of a $10 \%$ cysteine solution, $0.5 \%$ of $10 \mathrm{mg} / 100 \mathrm{~mL}$ dicloxacycline, and $1 \%$ of a solution of $10 \%$ lithium chloride (Homayouni et al., 2008). Both were incubated under anaerobic conditions at $37{ }^{\circ} \mathrm{C}$ for $72 \mathrm{~h}$ and the cell concentration was expressed as $\mathrm{CFU} / \mathrm{mL}$ of suspension.

\subsection{Microencapsulation procedure}

The activated cultures and the mango peel powder at $0,2 \%$, or $3 \% \mathrm{w} / \mathrm{v}$ were added to a $1 \% \mathrm{w} / \mathrm{w}$ sodium alginate solution. For formation of the microcapsules, the mixture was passed through a sterile syringe with a $21 \mathrm{G}$ needle and dropped from the height of $30 \mathrm{~cm}$ into a $2.5 \%$ calcium chloride solution under constant stirring (Karthikeyan et al., 2014). The formed microcapsules were kept in the solution for 35 min until hardening was achieved and subsequently separated and washed with distilled water (Jurkiewicz et al., 2011). The counts of probiotics were performed by diluting $1 \mathrm{~g}$ of microcapsules in $100 \mathrm{~mL}$ phosphate buffer to obtain a $10^{-2}$ dilution. Then the same counting methods mentioned in the activation of probiotics cultures were used, but the cell concentration was expressed as CFU/g of microcapsules.

\subsection{Ice cream manufacture}

The base mix for the ice cream had the following ingredients: UHT whole milk (Gloria, Peru), 36\% fat pasteurized milk cream (Gloria, Peru), granulated white sugar (Laredo, Peru), caboxymethyl cellulose (Dynacell, Unitech, China), emulsifier (Ludafa, Peru), vanilla essence (Pima, Peru), skim milk powder, and glucose. For manufacturing the vanilla-flavored ice cream, the whole milk (68.35\%) was heated together with the milk cream $(13 \%)$ at $50{ }^{\circ} \mathrm{C}$ and then the skim milk powder (3\%), sugar (12\%), glucose (2.8\%), carboxymethyl cellulose $(0.20 \%)$, emulsifier $(0.35 \%)$ and vanilla $(0.30 \%)$ were added. The mixture was homogenized using a blender (BRLY07, Oster, USA) for 2 min and pasteurized at $80^{\circ} \mathrm{C}$ for $20 \mathrm{~s}$. After that, the mixture was cooled to $40{ }^{\circ} \mathrm{C}$ and free or encapsulated probiotic cultures and mango peel powder were added according to the treatment, obtaining six formulations (Table 1). The total mixture was matured by storing at $4{ }^{\circ} \mathrm{C}$ for $12 \mathrm{~h}$ for subsequent mixing at $-4{ }^{\circ} \mathrm{C}$ for $15 \mathrm{~min}$ and storage at $-20^{\circ} \mathrm{C}$ (Jurkiewicz et al., 2011).

Table 1. Addition of probiotics and mango peel powder in the six ice cream formulations.

\begin{tabular}{|c|c|c|c|c|c|c|}
\hline Formulation & $\mathbf{F}_{1}$ & $\mathbf{F}_{2}$ & $\mathbf{F}_{3}$ & $\mathbf{F}_{4}$ & $F_{5}$ & $F_{6}$ \\
\hline Addition & \multicolumn{3}{|c|}{ Microencapsulated } & \multicolumn{3}{|c|}{ Free } \\
\hline Mango peel powder $(\%)$ & 0 & 2 & 3 & 0 & 2 & 3 \\
\hline Probiotics (CFU/g) & $10^{8}$ & $10^{8}$ & $10^{8}$ & $10^{8}$ & $10^{8}$ & $10^{8}$ \\
\hline
\end{tabular}

Source: The authors. Formulation 1: $\mathrm{F}_{1}$ (Probiotic and 0\% mango peel powder. Encapsulated.). Formulation 2: $\mathrm{F}_{2}$ (Probiotic and $2 \%$ mango peel powder. Encapsulated.). Formulation 3: $F_{3}$ (Probiotic and 3\% mango peel powder. Encapsulated.). Formulation 4: $\mathrm{F}_{4}$ (Probiotic and $0 \%$ mango peel powder. Free.). Formulation 5: $\mathrm{F}_{5}$ (Probiotic and $2 \%$ mango peel powder. Free.). Formulation 6: $\mathrm{F}_{6}$ (Probiotic and 3\% mango peel powder. Free.). 


\subsection{Probiotics viability in ice cream}

Viability was analyzed at $1,30,60,90,120$ and 180 days of storage at $-20{ }^{\circ} \mathrm{C}$ performing the same count methods described in the activation stage, but with the difference that the initial dilution $\left(10^{-1}\right)$ was obtained by diluting $25 \mathrm{~g}$ of ice cream at $4{ }^{\circ} \mathrm{C}$ in $225 \mathrm{~mL}$ of phosphate-buffered saline and the cell concentration was expressed as $\mathrm{CFU} / \mathrm{g}$ of ice cream. Improvement of probiotics survival was expressed in percentage and determined according to the following Equation 1:

$\frac{\mathcal{F}_{1}-\mathcal{F}_{2}}{\mathcal{F}_{1}} \times 100$

Where $\mathrm{F}_{1}$ is the reference formulation and $\mathrm{F}_{2}$ is the formulation for comparison.

\subsection{Overrun}

The procedure described by Akalın (2018), which consists in measuring the initial volume of the mixture and the final volume of the ice cream after mixing and freezing, was used.

\subsection{Apparent viscosity}

$500 \mathrm{~mL}$ of ice cream at $4{ }^{\circ} \mathrm{C}$ previously gently shaken to remove air was used. The test was performed on days 1 and 180 of storage using a Brookfield RV-III + digital rheometer with spindle no. 2 at $20 \mathrm{rpm}$. The results were expressed in mPa s (El-Sayed et al., 2014; Akalın \& Erisir, 2008).

\subsection{Overall acceptability}

It was evaluated using a hedonic 9-point scale ( 1 = "I completely dislike it", 5 = "I neither like nor dislike it", 9 = "I like it very much") The sensory evaluation was carried out in individual cabins under artificial lighting on days 1 and 180 of storage with 30 male (30\%) and 70 female (70\%) untrained, lactose tolerant, aged 16 to 22 years panelists, who were previously informed about the characteristics of the product to be evaluated, using approximately $25 \mathrm{~g}$ of each of the ice cream formulations at $4{ }^{\circ} \mathrm{C}$ served in single-use cups randomly coded (Jurkiewicz et al., 2011; Lucatto et al., 2020).

\subsection{Data analysis}

The results were treated statistically using the Minitab 16 software at a $95 \%$ confidence level. Analysis of variance (ANOVA) was applied to determine the significant difference between the treatments and the Duncan's Multiple Range test was used to measure specific differences between pair of means. For nonparametric analysis, Friedman and Wilcoxon signed-rank tests were applied.

\section{Results and discussions}

\subsection{Probiotics viability}

The initial counts of L. acidophilus and B. lactis in the ice cream ranged from $8 \times 10^{7}$ to $4 \times 10^{8} \mathrm{CFU} / \mathrm{g}$ (Figures 1 and 2), which decreased during storage at $-20^{\circ} \mathrm{C}$. However, after 180 days, it was not possible to reach the recommended minimum in some samples.

When probiotics were added free to the ice cream, the viability decreased because of the incorporation of oxygen, mechanic mixing, and ice crystals formed during the ice cream hardening, which physically damages their cell membrane. In addition, the low temperature retards the metabolic actions of probiotics, inducing them to a period of latency (Abghari et al., 2011; Caicedo,2010). 


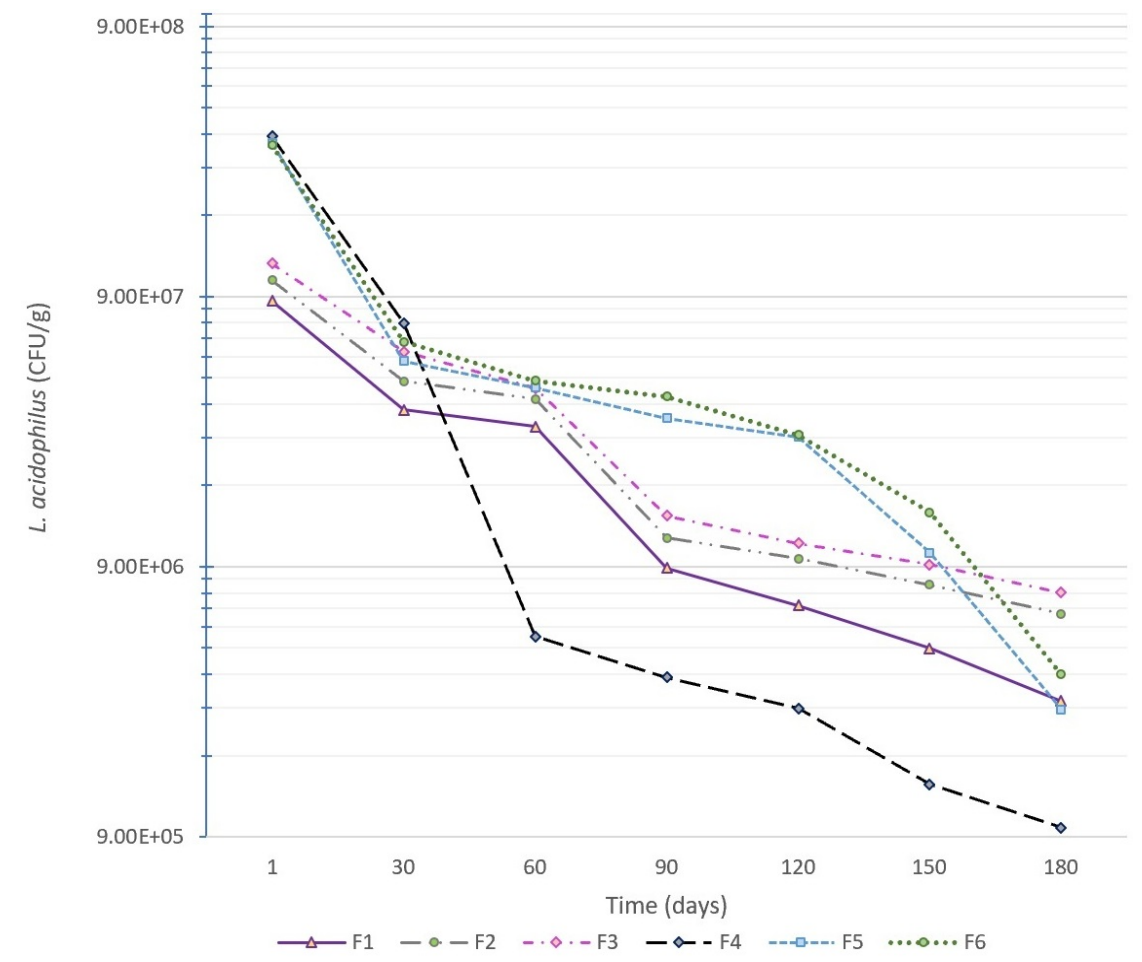

Figure 1. Viability of L. acidophilus (CFU/g) during 180 days of storage at $-20{ }^{\circ} \mathrm{C} . \mathrm{F}_{1}$ (Probiotic and $0 \%$ mango peel powder. Encapsulated.). $F_{2}$ (Probiotic and 2\% mango peel powder. Encapsulated.). $F_{3}$ (Probiotic and 3\% mango peel powder. Encapsulated.). $\mathrm{F}_{4}$ (Probiotic and $0 \%$ mango peel powder. Free.). $\mathrm{F}_{5}$ (Probiotic and 2\% mango peel powder.

Free.). $\mathrm{F}_{6}$ (Probiotic and 3\% mango peel powder. Free.).

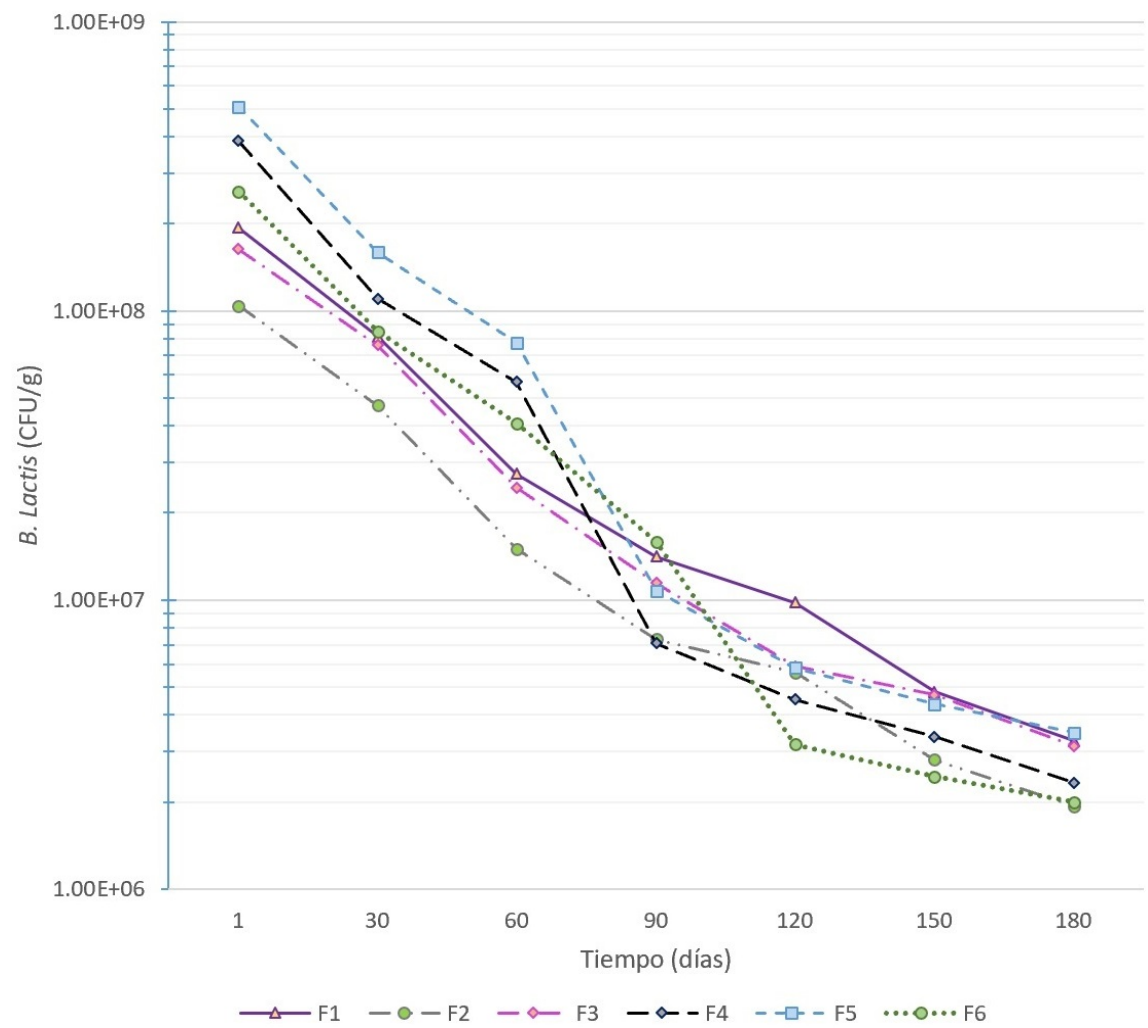

Figure 2. Viability of $\mathrm{B}$. lactis $(\mathrm{CFU} / \mathrm{g})$ during 180 days of storage at $-20{ }^{\circ} \mathrm{C} . \mathrm{F}_{1}$ (Probiotic and $0 \%$ mango peel powder. Encapsulated.). $F_{2}$ (Probiotic and 2\% mango peel powder. Encapsulated.). $F_{3}$ (Probiotic and 3\% mango peel powder. Encapsulated.). $F_{4}$ (Probiotic and 0\% mango peel powder. Free.). F5 (Probiotic and 2\% mango peel powder. Free.). F6 (Probiotic and 3\% mango peel powder. Free.). 
In contrast, the microencapsulation technique improved the viability of probiotics, considering that the microencapsulated microorganisms of formulations $F_{1}, F_{2}$, and $F_{3}$ took longer to decrease the logarithmic cycle during storage compared with the free microorganisms of formulations $\mathrm{F}_{4}, \mathrm{~F}_{5}$, and $\mathrm{F}_{6}$. As a result, the L. acidophilus count in the $\mathrm{F}_{1}$ formulation, with addition of encapsulated probiotics (no mango peel powder) decreased from $8.67 \times 10^{7}$ to $2.87 \times 10^{6} \mathrm{CFU} / \mathrm{g}$, achieving an improvement of $42.19 \%$ in probiotic survival compared with that of formulation $\mathrm{F}_{4}$, which had free probiotics (no mango peel powder), and its counts decreased from $3.52 \times 10^{8}$ to $9.73 \times 10^{5} \mathrm{CFU} / \mathrm{g}$. Similarly, the $B$. lactis counts in the $\mathrm{F}_{4}$ formulation at the beginning and the end of storage were $3.87 \times 10^{8}$ and $2.33 \times 10^{6} \mathrm{CFU} / \mathrm{g}$, respectively; whereas in the $\mathrm{F}_{1}$ formulation it decreased from $1.94 \times 10^{8}$ to $3.25 \times 10^{6} \mathrm{CFU} / \mathrm{g}$, achieving an improvement of $20.28 \%$ between the $\mathrm{F}_{1}$ and $\mathrm{F}_{4}$ formulations.

The improvement in the viability of probiotics by microencapsulation obtained in this study is consistent with those reported by other researchers, such as El-Sayed et al. (2014) in L. plantarum, L. casei and B. bifidum in ice cream for 90 days of storage at $20{ }^{\circ} \mathrm{C}$ and Karthikeyan et al. (2014), who reported a $30 \%$ improvement in the survival of L. acidophilus microencapsulated in a calcium alginate matrix and whey protein concentrate compared with free addition in ice cream after 180 days of storage at $-23{ }^{\circ} \mathrm{C}$.

The survival of L. acidophilus and B. lactis improved $24 \%$ and $5 \%$, respectively when comparing their counts in the $\mathrm{F}_{6}\left(2 \%\right.$ mango peel powder) and $\mathrm{F}_{4}(3 \%$ mango peel powder) formulations. The pectin present in the peel of fruits acts as a cryoprotectant (Ayar et al., 2018), and that is why the viability of probiotics also improved with the addition of mango peel powder, as it can be observed in Figures 1 and 2. Ayar et al. (2018) described the same behavior in probiotic ice creams with addition of fibers from fruits such as grapes ( $1 \%$ and $4 \%)$, apricot $(0.5 \%$ and $2 \%)$, and apple $(0.5 \%$ and $3 \%$ ) stored at $-20{ }^{\circ} \mathrm{C}$ for 60 days.

In formulations with microencapsulated probiotics and mango peel powder, the survival of $L$. acidophilus and B. lactis improved 18 and $3 \%$, respectively, when comparing their counts in the $\mathrm{F}_{3}$ (2\% mango peel powder) and $\mathrm{F}_{1}$ ( $3 \%$ mango peel powder) formulations. The grater loss of $B$. lactis compared with that of L. acidophilus in both free and microencapsulated addition can be explained in the fact that, unlike lactobacilli that are optional anaerobes, bifidobacteria are strictly anaerobic microorganisms; therefore, the incorporation of oxygen during the mixing of the ice cream affects them more severely and is the leading cause of their death (Homayouni et al., 2008).

\subsection{Overrun}

This physical characteristic varied from $21 \%$ to $72 \%$, according to the specifications of the Peruvian Technical Standard for ice cream (NTP 202.057), which establishes a 120\% maximum value for this characteristic. Studies addressing ice cream with probiotic microorganisms have reported values between $40 \%$ and $70 \%$ of overrun: El-Sayed et al. (2014) reported overrun between $63.46 \%$ and $66.56 \%$, whereas Jurkiewicz et al. (2011) reported values $<41 \%$. Parussolo et al. (2017) indicated that in ice cream with probiotic cultures, it is better to have low overrun values $(29 \%$ to $32 \%)$ to maximize the viability of microorganisms during production.

Table 2 shows the significant effect $(p<0.05)$ of microencapsulation and addition of mango peel powder on overrun. In the case of formulations $F_{1}, F_{2}$, and $F_{3}$, the increase in the amount of prebiotics did not significantly influence this variable, and similar values fluctuating between $70.44 \%$ and $72.97 \%$ were obtained. On the other hand, the overrun of formulations $\mathrm{F}_{4}, \mathrm{~F}_{5}$, and $\mathrm{F}_{6}$ decreased with addition of mango peel powder. Yang1lar $(2015,2016)$ studied the effect of fiber addition, such as dates, banana peel and peach peel $(1 \%$ and $2 \%)$, on the physicochemical characteristics of ice cream and reported similar behaviors. 
Table 2. Overrun, viscosity and overall acceptability in ice cream.

\begin{tabular}{cccccccc}
\hline $\begin{array}{c}\text { Storage time } \\
\text { (days) }\end{array}$ & Characteristics & $\mathbf{F}_{\mathbf{1}}$ & $\mathbf{F}_{\mathbf{2}}$ & $\mathbf{F}_{\mathbf{3}}$ & $\mathbf{F}_{\mathbf{4}}$ & $\mathbf{F}_{\mathbf{5}}$ & $\mathbf{F}_{\mathbf{6}}$ \\
\hline \multirow{2}{*}{1} & Overrun (\%) & $71.4^{\mathrm{a} *}$ & $72.97^{\mathrm{ab}}$ & $70.44^{\mathrm{b}}$ & $66.97^{\mathrm{c}}$ & $28.49^{\mathrm{d}}$ & $21.47^{\mathrm{e}}$ \\
\cline { 2 - 7 } & Viscosity (mPa s) & $223^{\mathrm{a}}$ & $223^{\mathrm{a}}$ & $231^{\mathrm{b}}$ & $225^{\mathrm{b}}$ & $989^{\mathrm{c}}$ & $1492^{\mathrm{d}}$ \\
\cline { 2 - 8 } & Overall acceptability (points) & 8.1 & 8.3 & 7.9 & 7.8 & 6.4 & 4.4 \\
\hline \multirow{2}{*}{180} & Viscosity (mPa s) & $282^{\mathrm{a}}$ & $292^{\mathrm{a}}$ & $295^{\mathrm{b}}$ & $284^{\mathrm{b}}$ & $1049^{\mathrm{c}}$ & $1582^{\mathrm{d}}$ \\
\cline { 2 - 8 } & Overall acceptability (points) & 7.7 & 7.6 & 7.7 & 7.4 & 6 & 3.9 \\
\hline
\end{tabular}

*For each characteristic, uppercase letters in the same row differ by Duncan's test $(p \leq 0.05)$. $\mathrm{F}_{1}$ : Encapsulated probiotics and $0 \%$ mango peel powder. $\mathrm{F}_{2}$ : Encapsulated probiotics and 2\% mango peel powder. $\mathrm{F}_{3}$ : Encapsulated probiotics and 3\% mango peel powder. $\mathrm{F}_{4}$ : Free probiotics and $0 \%$ mango peel powder. $\mathrm{F}_{5}$ : Free probiotics and $2 \%$ mango peel powder. $\mathrm{F}_{6}$ : Free probiotics and $3 \%$ mango peel powder.

\subsection{Apparent viscosity}

Microencapsulation and addition of mango peel powder had a significant effect $(p<0.05)$ on the apparent viscosity of ice cream. Table 2 shows that viscosity also increased with increasing the amount of free prebiotics and probiotics increased because of their interaction with the other components of the ice cream base mix (Akalin \& Erisir, 2008).

Yangilar (2016) reported an increase in viscosity with addition of $2 \%$ peach fiber in ice cream. Soukoulis et al. (2009) observed the same behavior with addition of fibers of oats, apples and wheat ( $2 \%$ and $4 \%)$ in ice cream. In the case of fiber-enriched ice cream, the high content of the insoluble part increases the viscosity by increasing the number of total solids in the mixture as a result of its water retention capacity and formation of an extensive network of hydrated cellulosic matter. Mango peel powder contains, on average, $20 \%$ of total dietary fiber, of which the largest amount (17\%) corresponds to insoluble fiber and the difference (3.7\%) corresponds to soluble fiber (Serna Cock \& Torres León, 2015).

In this study, it was observed that, during storage, between the initial and final day, there was a slight increase in viscosity, contrary to what was found by El-Sayed et al., who reported a notable decrease with the addition of L. plantarum, L. casei and B. bifidum microencapsulated separately in a sodium alginate matrix, starch $(0.5 \%)$, and concentrated whey protein $(1 \%)$ for 90 days of storage.

\subsection{Sensory analysis}

Table 2 shows the average scores of sensory evaluations obtained on days 1 and 180 of storage. The acceptance of formulations $F_{1}, F_{2}, F_{3}$, and $F_{4}$ were the highest, with scores of 7.7, 7.6, 7.7 and 7.4 points, respectively, at the end of the storage. The most prominent characteristics indicated by the panelists in the evaluation sheets were agreeable color, taste, and texture. Although most panelists noticed the color change in the capsules, they did not generate displeasure, which is a positive result.

In contrast, formulations $\mathrm{F}_{5}$ and $\mathrm{F}_{6}$ showed lower acceptance, with 6.0 and 3.9 points, respectively. The panelists indicated perception of excessive acidity, sandy texture, and brown color, which generated less pleasure. Akalın et al. (2018) mentioned that the addition of fibers, such as those from citrus fruits and some phenolic substances, causes a decrease in $\mathrm{pH}$ or an increase in acidity of ice cream.

Addition of free mango peel powder to ice cream decreased acceptance among the panelists. Parussolo et al. (2017), in the sensory evaluation of ice cream with addition of yacon flour (1.5\% and 3\%), reported a change in color to yellowish, as well as a sandy texture, which led lower scores ( 7.1 and 7.2 points, respectively) in the appearance and color characteristics compared with the control sample without addition of yacon flour, which received higher scores (7.7 points).

In the sensory analysis performed by Caicedo (2010), ice cream with microencapsulated probiotics had an acceptance between 6 and 8 points in the attributes of texture, appearance, color, aroma and flavor, even when the texture of the product was slightly grainy due to the presence of the microcapsules. This behavior was observed in the present study, as the microencapsulated formulations were the most accepted. Some 
panelists even indicated that the microcapsules were not unpleasant because they associated them with the presence of gummies suspended in the product; however, they recommended that they may have more flavor.

The Friedman test applied to the scores reported by the panelists on day 180 of storage showed statistically significant effect $(p<0.05)$ of microencapsulation and addition of mango peel powder on the overall acceptability of ice cream. Formulations $F_{1}$ and $F_{2}$ obtained the highest average ranges of 4.53 and 4.33 , respectively, as well as the highest mode, with 8 points in both cases (data not shown).

Next, the Wilcoxon signed-rank test was applied to compare the formulations with greater acceptance with the other treatments. Formulations $F_{1}$ and $F_{2}$ were statistically equal to formulations $F_{3}$ and $F_{4}$, but different from the others, suggesting that the $\mathrm{F}_{2}$ formulation was the best, because it was one of the most accepted, with adequate quality characteristics.

\section{Conclusions}

Microencapsulation and addition of mango peel powder showed a significant effect on all characteristics evaluated. Addition of mango peel powder increased the viability of Lactobacillus acidophilus and Bifidobacterium lactis and viscosity of the ice cream, but decreased its overrun and overall acceptability; in contrast, microencapsulation improved all the characteristics of ice cream without affecting its overall acceptability.

The ice cream formulation with microencapsulated probiotics and $2 \%$ mango peel powder $\left(\mathrm{F}_{2}\right)$ was considered the best product. This formulation is promising for future commercial application because it presented the largest probiotics population and appropriate count of prebiotics that guarantee its viability during storage.

\section{References}

Abghari, A., Sheikh-Zeinoddin, M., \& Soleimanian-Zad, S. (2011). Nonfermented ice cream as a carrier for Lactobacillus acidophilus and Lactobacillus rhamnosus. International Journal of Food Science \& Technology, 46(1), 84-92. http://dx.doi.org/10.1111/j.1365-2621.2010.02453.x

Akalın, A., \& Erisir, D. (2008). Effects of inulin and oligofructose on the rheological characteristics and probiotic culture survival in low-fat probiotic ice cream. Journal of Food Science, 73(4), M184-M188. PMid:18460135. http://dx.doi.org/10.1111/j.1750-3841.2008.00728.x

Akalın, A., Kesenkas, H., Dinkci, N., Unal, G., Ozer, E., \& Kinik, O. (2018). Enrichment of probiotic ice cream with different dietary fibers: Structural characteristics and culture viability. Journal of Dairy Science, 101(1), 37-46. PMid:29103712. http://dx.doi.org/10.3168/jds.2017-13468

Araújo, E., Pires, A., Pinto, M., Jan, G., \& Carvalho, A. (2012). Probiotics in dairy fermented products. In E. Rigobelo (Ed.), Probiotics. London: IntechOpen.

Ayar, A., Sicramaz, H., Ôztûrk, S., \& Ôztûrk Yilmaz, S. (2018). Probiotic properties of ice creams produced with dietary fibres from by-products of the food industry. International Journal of Dairy Technology, 71(1), 174-182. http://dx.doi.org/10.1111/14710307.12387

Balthazar, C. F., Silva, H. L. A., Esmerino, E. A., Rocha, R. S., Moraes, J., Carmo, M. A. V., Azevedo, L., Camps, I., Abud, Y. K. D., Sant'Anna, C., Franco, R. M., Freitas, M. Q., Silva, M. C., Raices, R. S. L., Escher, G. B., Granato, D., Ranadheera, C. S., Nazzaro, F., \& Cruz, A. G. (2017). The addition of inulin and Lactobacillus casei 01 in sheep milk ice cream. Food Chemistry, 252, 397. PMid:29291874. http://dx.doi.org/10.1016/j.foodchem.2018.01.186

Caicedo, Y. (2010). Estudio de la viabilidad de la incorporación de las bacterias probióticas micro encapsuladas en helado (Tesis de especialidad). Universidad Nacional de Colombia, Bogotá

Champagne, C., Gomes da Cruz, A., \& Daga, M. (2018). Strategies to improve the functionality of probiotics in supplements and foods. Current Opinion in Food Science, 22, 160-166. http://dx.doi.org/10.1016/j.cofs.2018.04.008

Cruz, A., Antunes, A., Sousa, A., Faria, J., \& Saad, S. (2009). Ice-cream as a probiotic food carrier. Food Research International, 42(9), 1233-1239. http://dx.doi.org/10.1016/j.foodres.2009.03.020

El-Sayed, H., Salama, H., \& El-Sayed, S. (2014). Production of symbiotic ice cream. International Journal of Chemtech Research, 7(1), 138-147.

Gibson, G. R., Hutkins, R., Sanders, M. E., Prescott, S. L., Reimer, R. A., Salminen, S. J., Scott, K., Stanton, C., Swanson, K S., Cani, P. D., Verbeke, K., \& Reid, G. (2017). The International Scientific Association for Probiotics and Prebiotics (ISAPP) consensus statement on the definition and scope of prebiotics. Nature Reviews. Gastroenterology \& Hepatology, 14(8), 491502. PMid:28611480. http://dx.doi.org/10.1038/nrgastro.2017.75

Guarner, F., Sanders, M. E., Eliakim, R., Fedorak, R., Gangl, A., Garisch, J., Kaufmann, P., Karakan, T., Khan, A. G., Kim, N., Paula, J. A., Ramakrishna, B., Shanahan, F., Szajewska, H., Thomson, A., \& Le Mair, A. (2017). World Gastroenterology Organisation Global guidelines: Probiotics and prebiotics. Milwaukee, WI: World Gastroenterology Organization. 
Hill, C., Guarner, F., Reid, G., Gibson, G. R., Merenstein, D. J., Pot, B., Morelli, L., Canani, R. B., Flint, H. J., Salminen, S., Calder, P. C., \& Sanders, M. E. (2014). The International Scientific Association for Probiotics and Prebiotics consensus statement on the scope and appropriate use of the term probiotic: Expert consensus document. Nature Reviews. Gastroenterology \& Hepatology, 11(8), 506-514. PMid:24912386. http://dx.doi.org/10.1038/nrgastro.2014.66

Homayouni, A., Azizi, A., Ehsani, M., Yarmand, M., \& Razavi, S. (2008). Effect of microencapsulation and resistant starch on the probiotic survival and sensory properties of symbiotic ice cream. Food Chemistry, 111(1), 50-55. http://dx.doi.org/10.1016/j.foodchem.2008.03.036

Jibaja Espinoza, L. M. (2014). Determinación de la capacidad antioxidante y análisis composicional de harina de cáscara de mango, Manguifera Indica, variedad "Criollo". Cientifi-K, 2(1), 62-65. Retrieved in 2019, November 12, from http://revistas.ucv.edu.pe/index.php/CIENTIFI-K/article/view/290

Jurkiewicz, C., Boscarioli, M., Ferreira, R., Ribeiro, E., Prieto, W., \& Kunigk, L. (2011). Microencapsulation of probiotic bacteria with alginate and prebiotic and evaluation of survival in ice cream. In 11th International Congress on Engineering and Food. Athens.

Kalicka, D., Znamirowska, A., Pawlos, M., Buniowska, M., \& Szajnar, K. (2019). Physical and sensory characteristics and probiotic survival in ice cream sweetened with various polyols. International Journal of Dairy Technology, 72(3), 456-465. http://dx.doi.org/10.1111/1471-0307.12605

Karthikeyan, N., Elango, A., Kumaresan, G., Gopalakrishnamurty, T., \& Raghunath, B. (2014). Enhancement of probiotic viability in ice cream by microencapsulation. International Journal of Science, Environment and Technology, 3(1), 339-347.

Khosravi Zanjani, M. A., Ghiassi Tarzi, B., Sharifan, A., \& Mohammadi, N. (2014). Microencapsulation of probiotics by calcium alginate-gelatinized starch with quitosan coating and evaluation of survival in simulated human gastrointestinal condition. Iranian Journal of Pharmaceutical Research, 13(3), 843-852. PMid:25276184

Lucatto, J., Silva-Buzanello, R., Mendonça, S., Lazarotto, T., Sanchez, J., Bona, E., \& Drunkler, D. (2020). Performance of different microbial cultures in potentially probiotic and prebiotic yoghurts from cow and goat milks. International Journal of Dairy Technology, 73(1), 144-156. http://dx.doi.org/10.1111/1471-0307.12655

Martín, M., Lara-Villoslada, F., Ruiz, M., \& Morales, M. (2015). Microencapsulation of bacteria: A review of different technologies and their impact on the probiotic effects. Innovative Food Science \& Emerging Technologies, 27, 15-25.

http://dx.doi.org/10.1016/j.ifset.2014.09.010

Pacheco, A. (2015). Efecto de compuestos fenólicos presentes en mango cv. Ataulfo, sobre el crecimiento de bacterias patógenas y benéficas (Tesis de maestría). Centro de Investigación en Alimentación y Desarrollo, Hermosillo, México.

Parussolo, G., Busatto, R., Schmitt, J., Pauletto, R., Schons, P., \& Ries, E. (2017). Synbiotic ice cream containing yacon flour and Lactobacillus acidophilus NCFM. Lebensmittel-Wissenschaft + Technologie, 82, 192-198. http://dx.doi.org/10.1016/j.lwt.2017.04.049

Peredo, A. (2014). Enriquecimiento de una pasta de aceituna con bacterias potencialmente probióticas encapsuladas con alginato y prebióticos (Tesis de maestría). Universidad Veracruzana, Veracruz, México.

Pradeep Prasanna, P. H., \& Charalampopoulos, D. (2019). Encapsulation in an alginate-goats' milk-inulin matrix improves survival of probiotic Bifidobacterium in simulated gastrointestinal conditions and goats' milk yoghurt. International Journal of Dairy Technology, 72(1), 132-141. http://dx.doi.org/10.1111/1471-0307.12568

Ranadheera, S., Naumovski, N., \& Ajlouni, S. (2018). Non-bovine milk products as emerging probiotic carriers: Recent developments and innovations. Current Opinion in Food Science, 22, 109-114. http://dx.doi.org/10.1016/j.cofs.2018.02.010

Serna Cock, L., \& Torres León, C. (2015). Potencial agroindustrial de cáscaras de mango (Manguifera indica) variedades Keitt y Tommy Atkins. Acta Agronomica, 64(2), 110-115. http://dx.doi.org/10.15446/acag.v64n2.43579

Serrano-Casas, V., Pérez-Chabela, M. L., Cortés-Barberena, E., \& Totosaus, A. (2017). Improvement of latic acid bacteria viability in acid conditions employing agroindustrial co-products as prebiotic on alginate ionotropic gel matrix co-encapsulation. Journal of Functional Foods, 38, 293-297. http://dx.doi.org/10.1016/j.jff.2017.09.048

Soukoulis, C., Lebesi, D., \& Tzia, C. (2009). Enrichment of ice cream with dietary fibre: Effects on rheological properties, ice crystallization and glass transition phenomena. Food Chemistry, 115(2), 665-671.

http://dx.doi.org/10.1016/j.foodchem.2008.12.070

Yangılar, F. (2015). Effects of green banana flour on the physical, chemical and sensory properties of ice cream. Food Technology and Biotechnology, 53(3), 315-323. PMid:27904363.

Yangılar, F. (2016). Production and evaluation of mineral and nutrient contents, chemical composition, and sensory properties of ice creams fortified with laboratory-prepared peach fibre. Food \& Nutrition Research, 60(1), 31882. PMid:27814781. http://dx.doi.org/10.3402/fnr.v60.31882

Funding: None. 